\title{
Evaluation of milled pearl millet in the feeding of growing rabbits ${ }^{1}$
}

\author{
Fernanda Catelan², Claudio Scapinello², Josianny Limeira Figueira ${ }^{2}$, Andréia Fróes Galuci \\ Oliveira², Ana Carolina Monteiro Motta ${ }^{2}$
}

\author{
${ }^{1}$ Research financed by CAPES. \\ 2 Programa de Pós-Graduação em Zootecnia/Universidade Estadual de Maringá, Maringá - Paraná/Brasil.
}

\begin{abstract}
Two experiments were carried out in order to estimate the nutritional value and the performance of growing rabbits fed different levels of pearl millet (ADR 7010). In the digestibility trial, nutritional values of pearl millet were determined in 22 45-day-old New Zealand White rabbits, allotted in a completely randomized design, subjected to two treatments - a reference diet and a test diet with $70 \%$ of its volume composed of reference diet and $30 \%$ of pearl millet - and 11 replications. The apparent digestibility values of dry matter, crude protein, neutral detergent fiber and gross energy of the pearl millet were 88.7, 85.4, 24.4 and 75.0\%, respectively. In the performance trial, 120 32-day-old New Zealand White rabbits were used. Rabbits were allotted in a completely randomized design and subjected to six treatments, with 10 replications and two animals for each experimental unit. The diets were formulated with increasing levels of pearl millet (20, 40, 60, 80 and $100 \%)$, substituting the corn in the reference diet, according to the digestible energy. No differences were observed in daily feed intake, daily weight gain, feed conversion, carcass traits and feed cost per kilogram of rabbit. Regardless of the amount of corn substituted, pearl can replace corn in diets for growing rabbits.
\end{abstract}

Key Words: carcass, digestibility, energy value, performance

\section{Introduction}

Pearl millet (Pennisetum glaucum) is considered an alternative ingredient to supply energy in feed for rabbits. It is a cereal of worldwide importance, regarded as an excellent alternative for the production of grains and fodder (Café et al., 2002). It is also the sixth most produced cereal in the world (154 million tons), and it is commonly used in Africa, Asia and North America in human and animal diets (FAO, 2005). In Brazil, pearl millet is grown in the south and southeast regions, and the average grain production is 2,680 kg grains/ha (Geraldo et al., 2000).

Considering its low cost and the high quality of its grains, pearl millet can be an important alternative rawmaterial for the preparation of animal feed, once it has about $95 \%$ of the energetic value of corn, with higher levels and better quality of proteins, varying from 11.64 to $14.07 \%$, according to the values described by Bastos et al. (2006) and Moreira et al. (2007), respectively, in the natural matter.

Furlan et al. (2003) evaluated the use of common pearl millet or IAPAR IA 98301, substituting corn, and verified that the performance of rabbits, from weaning to slaughter, was not affected.

The significant growth of pearl millet production on Brazilian farms, the introduction of new varieties of this cereal and the lack of information regarding its use for feeding rabbits justify the research to evaluate the inclusion of this product in diet for rabbits.

This study was carried out to quantify the nutritional value of milled pearl millet grain for feeding rabbits and evaluates the performance of New Zealand White rabbits, from weaning to slaughter; those animals were fed diets containing different levels of milled pearl millet grains gradually substituting corn, based on digestible energy.

\section{Material and Methods}

The experiments were carried out at the Setor de Cunicultura of Fazenda Experimental de Iguatemi of Universidade Estadual de Maringá, located in Maringá, Paraná state, Brazil (2325.E, 5157.W, 550 m altitude), from February to April of 2008, with highest mean temperature of $26.22^{\circ} \mathrm{C}$, lowest mean temperature of $16.66^{\circ} \mathrm{C}$ and relative air humidity of $73.58 \%$.

Two experiments were carried out in order to quantify the nutritional value of pearl millet, by means of a digestibility trial, and also to evaluate the use of pearl millet for feeding growing rabbits.

Pearl millet genotype ADR 7010 was used; it was obtained from the company Sementes Adriana, and milled in hammermill, with a sieve of $3 \mathrm{~mm}$ of porosity. 
For the digestibility trial, 22 New Zealand White rabbits were used. Eleven animals were male and 11 were female, at the age of 45 days. Animals were individually lodged in metabolism cages equipped with an automatic nipple drinker and a semi-automatic feeder made of galvanized sheet. In the lower part, the cages had nylon screens for feces collection. The cages were established in a brick shed, covered with fibro-asbestos roofing, with $4.0 \mathrm{~m}$ ceiling, brickwork floor and brickwork side walls of $0.5 \mathrm{~m}$; the other parts were made of plastic screens and curtains so as to retain the wind.

The animals were arranged in a completely randomized design, for two different treatments: a reference diet and a test diet. The latter was composed of $70 \%$ of the reference diet and 30\% of pearl millet; the experiment had 11 replications. The reference diet (Table 1) was formulated for growing rabbits, based upon the recommendations of De Blas \& Wiseman (1998).

The experimental period lasted 14 days; 10 days were intended for adaptation to the feed and 4 days were used for the total collection of the feces, according to the European Reference Method for in vivo digestibility trials

Table 1 - Energetic, chemical and percentage composition of reference diet

\begin{tabular}{|c|c|}
\hline Ingredients & $\%$ \\
\hline Corn & 25.62 \\
\hline Soybean meal & 14.00 \\
\hline Wheat bran & 23.00 \\
\hline Alfalfa hay & 17.00 \\
\hline Coast cross hay & 17.00 \\
\hline Common salt & 0.40 \\
\hline Dicalcium & 1.00 \\
\hline Limestone & 1.20 \\
\hline Mineral and vitamin suplement ${ }^{1}$ & 0.50 \\
\hline L-lysine HCL & 0.15 \\
\hline Dl-methionine & 0.12 \\
\hline Cycostat* & 0.06 \\
\hline Total & 100 \\
\hline \multicolumn{2}{|c|}{ Chemical composition, on a dry matter basis } \\
\hline Digestible energy, kcal/kg² & 2,640 \\
\hline Crude protein ${ }^{3}$, \% & 16.13 \\
\hline Crude fiber, \% & 13.66 \\
\hline Neutral detergent fiber ${ }^{3}$ \% & 32.46 \\
\hline Acid detergent fiber ${ }^{3}$, \% & 16.38 \\
\hline Starch $^{3}, \%$ & 25.42 \\
\hline Calcium $^{2}, \%$ & 0.80 \\
\hline Phosphorus $^{2}$, \% & 0.52 \\
\hline Methionine + total cystine ${ }^{2}$, \% & 0.60 \\
\hline Total lysine ${ }^{2}, \%$ & 0.80 \\
\hline \multicolumn{2}{|c|}{$\begin{array}{l}{ }^{1} \text { Nuvital, composition per kg of product: vit. A - } 600,000 \mathrm{UI} \text {; vit. D - } 100,000 \\
\text { UI; vit. E - 8,000 mg; vit. K3 - } 200 \mathrm{mg} \text {; vit. B1 - } 400 \mathrm{mg} \text {; vit. B2 - } 600 \mathrm{mg} \text {; vit. } \\
\text { B6- } 200 \mathrm{mg} \text {; vit. B12 - 2,000 mcg; pantothenic acid - 2,000 mg; choline - 70,000 mg; } \\
\text { Fe - 8,000 mg; Cu - 1.200 mg; Co - } 200 \mathrm{mg} \text {; Mn - } 8.600 \mathrm{mg} \text {; Zn - 12,000 mg; I - } \\
64 \mathrm{mg} \text {; Se - } 16 \mathrm{mg} \text {; methionine - } 120,000 \mathrm{mg} \text {; antioxidant - } 20.000 \mathrm{mg} \text {. } \\
\left.{ }^{*} \text { Robenidine-based active ingredient ( } 6.6 \%\right) \text {. } \\
{ }^{2} \text { Calculated according to the feed composition presented by Rostagno et al. } \\
\text { (2005). } \\
3 \text { Values analyzed at the Laboratory of Feeds and Animal Nutrition of the } \\
\text { Department of Animal Science of Universidade Estadual de Maringá. }\end{array}$} \\
\hline
\end{tabular}

(Perez et al., 1995). During all the experiment, the animals were fed ad libitum, once a day in the morning, and had free access to water.

Feces were collected on a daily basis, in the morning, stored in a freezer at $-10^{\circ} \mathrm{C}$ and, at the end of the collection period, defrosted and kept in a ventilated oven at $55^{\circ} \mathrm{C}$ for 72 $\mathrm{h}$ for pre-drying. After that, they were exposed to open air for balancing the ambient temperature and humidity. Then they were weighed, homogenized and milled in a mill with a $1 \mathrm{~mm}$ sieve, for analysis of dry matter (DM), crude protein (CP), gross energy (GE), neutral detergent fiber (NDF) and acid detergent fiber (ADF), according to Silva \& Queiroz (2002) (Table 2).

The pearl millet coefficients of digestibility of dry matter, gross energy, crude protein, neutral detergent fiber and acid detergent fiber were calculated according to Matterson et al. (1965).

In order to evaluate the performance, 120 New Zealand White rabbits - 60 male and 60 female - at the age of 32 to 70 days were used. Animals were lodged in galvanized wire cages, equipped with an automatic drinker and a semiautomatic feeder made of galvanized sheet, located in a brick shed, covered with French roofing, with $3.2 \mathrm{~m}$ ceiling, brickwork floor, and brickwork side walls of $0.5 \mathrm{~m}$; the other parts were made of plastic screens and curtains for retaining the wind.

The animals used in the experiment were distributed in a completely randomized design, with six treatments, ten replications and two animals per experimental unity. The treatments consisted of a reference diet, formulated according to the recommendations for growing rabbits (De Blas \& Wiseman, 1998) and five other different diets with gradual substitution of corn (20, 40, 60, 80 and 100\%) for pearl millet, based on the digestible energy (Table 3). The experimental diets were dry-pelletized, and, during the whole experiment, animals were fed ad libitum once a day, and had free access to water.

Table 2 - Chemical composition of corn and pearl millet grains, on a dry matter basis

\begin{tabular}{lcc}
\hline Nutrients & $\begin{array}{c}\text { Corn } \\
\text { grains }\end{array}$ & $\begin{array}{c}\text { Pearl millet } \\
\text { grains }\end{array}$ \\
\hline Crude protein (\%) & 8.89 & 13.8 \\
Crude fiber (\%) & 2.53 & 2.80 \\
Neutral detergent fiber (\%) & 13.20 & 17.6 \\
Acid detergent fiber (\%) & 2.95 & 3.42 \\
Gross energy (kcal/kg) & 4426 & 4480 \\
Starch (\%) & 74.56 & 64.93 \\
Ether extract (\%) & 3.67 & 4.34 \\
Nitrogen-free extract (\%) & 86.96 & 1.91 \\
Ash (\%) & 1.34 & \\
Analysis carried out at the Laboratory of Feeds and Animal Nutrition of \\
Universidade Federal de Maringá.
\end{tabular}

R. Bras. Zootec., v.41, n.8, p.1866-1871, 2012 
Table 3 - Percentage and chemical composition of experimental diets using pearl millet

\begin{tabular}{|c|c|c|c|c|c|c|}
\hline \multirow[t]{2}{*}{ Ingredients } & \multirow[t]{2}{*}{ Reference diet } & \multicolumn{5}{|c|}{ Levels of substitution of corn for pearl millet (\%) } \\
\hline & & 20 & 40 & 60 & 80 & 100 \\
\hline Corn & 27.00 & 21.60 & 16.20 & 10.80 & 5.4 & 0 \\
\hline Wheat bran & 23.73 & 23.66 & 23.59 & 23.53 & 23.46 & 23.40 \\
\hline Soybean meal & 11.00 & 10.80 & 10.60 & 10.40 & 10.20 & 10.00 \\
\hline Alfalfa hay & 18.00 & 17.02 & 16.04 & 15.06 & 14.08 & 13.10 \\
\hline Dicalcium & 0.50 & 0.54 & 0.58 & 0.62 & 0.66 & 0.70 \\
\hline Limestone & 0.60 & 0.62 & 0.64 & 0.66 & 0.68 & 0.70 \\
\hline Salt & 0.40 & 0.40 & 0.40 & 0.40 & 0.40 & 0.40 \\
\hline L-lysine $\mathrm{HCl}$ & 0.15 & 0.15 & 0.16 & 0.16 & 0.17 & 0.18 \\
\hline $\operatorname{Premix}^{1}$ & 0.50 & 0.50 & 0.50 & 0.50 & 0.50 & 0.50 \\
\hline DL-methionine & 0.12 & 0.11 & 0.11 & 0.11 & 0.11 & 0.11 \\
\hline Crude protein ${ }^{3}, \%$ & 16.74 & 17.14 & 17.12 & 16.77 & 17.32 & 16.8 \\
\hline Crude fiber ${ }^{3}, \%$ & 13.66 & 13.62 & 13.58 & 13.54 & 13.51 & 13.47 \\
\hline Acid detergent fiber $^{3}, \%$ & 18.88 & 17.84 & 18.7 & 18.78 & 16.53 & 17.19 \\
\hline Neutral detergent fiber $^{3}$, \% & 35.27 & 34.67 & 35.37 & 35.64 & 33.96 & 34.43 \\
\hline $\operatorname{Starch}^{3}, \%$ & 25.93 & 25.87 & 25.85 & 25.81 & 25.78 & 25.75 \\
\hline Total phosphorus, \% & 0.52 & 0.52 & 0.53 & 0.53 & 0.53 & 0.54 \\
\hline Calcium $^{2}, \%$ & 0.79 & 0.80 & 0.80 & 0.80 & 0.80 & 0.80 \\
\hline Methionine + cystine $^{2}, \%$ & 0.60 & 0.60 & 0.60 & 0.60 & 0.60 & 0.60 \\
\hline Lysine $^{2}, \%$ & 0.80 & 0.80 & 0.80 & 0.80 & 0.80 & 0.80 \\
\hline Cost/kg (R\$) & 0.62 & 0.60 & 0.60 & 0.60 & 0.59 & 0.58 \\
\hline
\end{tabular}

The feed provided and the animals were weighed at the beginning of the experiment, at the age of 32 days, 50 days and at the end of the experiment, at the age of 70 days. The performance characteristics evaluated were: final weight, daily weight gain, daily feed intake and feed conversion.

The animals were slaughtered without previous fasting; they were stunned and then their jugular was cut. Weight and the productivity of the hindquarters, loin, forelimbs and of the thoracic-cervical region carcass were evaluated. For determining carcass weight, warm carcass with the head and without the edible viscera (heart, liver and kidneys) was considered.

To verify the economic viability of the substitution of corn for pearl millet, the equation described by Bellaver et al. (1985) was used. It calculates the average cost of experimental feeds per kilogram of body weight gained. In order to calculate the cost of experimental feeds, the prices of ingredients in the region of Maringá (Paraná - Brazil), during the month of July, 2009, were adopted.

The results of the variables studied were analyzed statistically, by means of program SAEG (Sistema para
Análises Estatísticas e Genéticas, version 8.0), adopting $\alpha=0.05$.

\section{Results and Discussion}

Similar results were obtained by Furlan et al. (2003), who found the coefficient of dry matter digestibility of 85.62; 88.26 and $88.14 \%$ for common pearl millet, BN2 and IAPAR, respectively, also for rabbits. However, Lawrence et al. (1995) found values of coefficient of dry matter digestibility of $75.5,78.8$ and $63.07 \%$ for two varieties of

Table 4 - Coefficient of digestibility and digestible nutrients of pearl millet ADR 7010, based on total dry matter

\begin{tabular}{lcc}
\hline Nutrients & $\begin{array}{c}\text { Coefficient of } \\
\text { digestibility (\%) }\end{array}$ & $\begin{array}{c}\text { Digestible } \\
\text { nutrients }\end{array}$ \\
\hline Dry matter & 88.71 & $81.25 \%$ \\
Crude protein & 85.39 & $11.77 \%$ \\
Neutral detergent fiber & 24.35 & $4.28 \%$ \\
Acid detergent fiber & 18.56 & $0.63 \%$ \\
Gross energy & 75.02 & $3,361 \mathrm{kcal} / \mathrm{kg}$ \\
\hline Analysis carried out at the Laboratory of Feeds and Animal Nutrition of
\end{tabular}
Universidade Federal de Maringá. 
pearl millet and for common pearl millet, respectively, which are values lower than the ones found in this experiment (Table 4).

Similar values of crude protein digestibility coefficient of pearl millet were found by Fialho et al. (1999) and Pinheiro et al. (2003): 86.20 and $86.25 \%$, on a DM basis, respectively. The values observed by Furlan et al. (2003) were 75.86, 87.65 and $83.51 \%$ crude protein digestibility coefficient, also close to the ones found in this experiment.

The fact that pearl millet has a higher protein value than corn may contribute to reduction of the amount of soybean meal, reducing the cost of the diet.

Variations in the chemical composition of pearl millet, according to Adeola \& Orban (1995), are related to the genotype and the environment, which implies that the crude protein of pearl millet grain can be increased by genetic improvements of the plant and enhancements in the production conditions. Factors such as soil composition and the fertilizer application period could also influence the levels of protein of that cereal. Therefore, nutritional evaluations of new varieties, concerning pearl millet, are important for its correct use in animal diets.

When evaluating common pearl millet, BN2 and IAPAR for rabbits, Furlan et al. (2003) found values of 22.17, 23.41 and $29.99 \%$, for the NDF digestibility coefficient, and values of 2.58, 3.76 and 3.26\%, respectively, for digestible NDF. Those authors also obtained values for the coefficient of gross energy digestibility of $83.16,87.61$ and $87.49 \%$ for the varieties common pearl millet, BN2 and IAPAR, respectively. Lower energy digestibility coefficients were obtained by Bastos et al. (2005), with pigs, for common pearl millet, IAPAR and BN2. The values were 63.09, 71.57 and $67.39 \%$, respectively. Differences between cultivars and in the digestive process aspects between the species, in which the rabbit, besides having enzymatic digestion, presents a significant fermentation process in the caecum, along with the habit of coprophagy, might explain its higher efficiency in the energy use, if compared with pigs.

Bastos et al. (2005) noticed that the different pearl millet cultivars have varied chemical compositions, which can result in differences in nutritional values between them. Thus, it is important to identify the cultivars and to study the impact on their use for making animal feeds, due to the availability of new cultivars in the Brazilian market.

The values of daily weight gain (DWG), daily feed intake (DFI) and feed conversion (FC) found in this study for pearl millet ADR 7010 (Table 5) were similar to the ones found by Furlan et al. (2003), who did not observe differences in the performance of rabbits when corn was substituted by common pearl millet. According to the same authors, with a substitution of $100 \%$, the results were satisfactory, presenting values of DWG, DFI and FC of 26.87, 96.46 and $3.59 \mathrm{~g}$, respectively.

The similarity of the performance results between the diets might be explained by the very similar nutritional values presented by pearl millet and corn, mainly concerning digestible energy, crude protein and ether extract. Despite the fact that the levels of the fiber components of pearl millet are slightly higher than the ones found in corn, it should be highlighted that the digestive process of rabbits is peculiar, once it allows more efficiency in using the energy supplied by the diets with this characteristic, if compared with other non-ruminants.

Information on the use of pearl millet in diets concerning performance of rabbits is scarce. However, Rodrigues et al. (2001), after having worked with inclusion levels up to $40 \%$ of pearl millet in feed for broilers, noticed linear improvement in DWG and in FC and, since the diets had the same amount

Table 5 - Performance of rabbits fed diets containing different levels of pearl millet substituting corn

\begin{tabular}{|c|c|c|c|c|c|c|c|c|}
\hline \multirow[t]{2}{*}{ Characteristics } & \multirow[t]{2}{*}{ Reference diet } & \multicolumn{5}{|c|}{ Levels of substitution of corn by pearl millet ADR 7010 (\%) } & \multirow[t]{2}{*}{ Mean } & \multirow[t]{2}{*}{ CV (\%) } \\
\hline & & 20 & 40 & 60 & 80 & 100 & & \\
\hline AW50 (g) & 1448 & 1454 & 1424 & 1429 & 1447 & 1394 & 1428 & 10.32 \\
\hline DWG 32-50 (g) & 40 & 42 & 40 & 40 & 41 & 38 & 40 & 20.54 \\
\hline DWG $32-70$ (g) & 38 & 39 & 38 & 38 & 38 & 36 & 38 & 14.13 \\
\hline DFI $32-50$ (g) & 106 & 101 & 98 & 99 & 102 & 95 & 99 & 14.64 \\
\hline FC $32-70$ & 3.08 & 3.15 & 3.24 & 3.18 & 3.18 & 3.2 & 3.19 & 10.17 \\
\hline Cost/kg WG 32-50 & 1.62 & 1.46 & 1.34 & 1.39 & 1.55 & 1.38 & 1.43 & 14.82 \\
\hline Cost/kg WG $32-70$ & 1.91 & 1.94 & 1.94 & 1.91 & 1.87 & 1.86 & 1.89 & 10.07 \\
\hline
\end{tabular}

R. Bras. Zootec., v.41, n.8, p.1866-1871, 2012 
of nutrients, the authors attributed the improvement to the increase in oil percentage as the levels of pearl millet were increased, which made the feeds become more easily digested. Likewise, Davis et al. (2003), evaluating the substitution of corn by pearl millet TifGrain 102 for broilers of 1-42 days of age, verified that the inclusion of pearl millet at up to $50 \%$ of the diet improved the weight of birds, although the FC did not differ from the broilers fed a cornbased diet. Gomes et al. (2008), evaluating the use of common pearl millet in diets for broilers, concluded that pearl millet can be included to the diets at up to $40 \%$ of the diet without altering the performance of birds. This fact corroborates the assumption that the pearl millet grain, obtained from specific hybrids, can have nutritional values that are higher than the levels found in common pearl millet, as happens with corn.

On the other hand, Murakami et al. (2009), analyzing the use of pearl millet ADR 7010 to feed broilers substituting corn, verified that FC up to 21 days and weight gain up to 41 days were not influenced, regardless of the substitution levels. However, they observed a DFI linear increase and FC linear worsening in the total period of the experiment.

There was no difference $(\mathrm{P}>0.05)$ in the results of economical analysis (Table 5) for cost of feeds prepared with gradual inclusion of pearl millet substituting corn. This shows that the inclusion of pearl millet ADR 7010, completely replacing corn in diets for rabbits in the growing phase, is economically viable.

Those results are in accordance with Bastos et al. (2004), who studied the use of pearl millet IAPAR-IA98301 in diets for pigs in the starter phase and affirmed that the inclusion of $60 \%$ of pearl millet was the best in economical terms; Bastos et al. (2006), evaluating the economical viability of using feeds with increasing levels of pearl millet IAPAR to feed pigs, concluded that the inclusion of up to $75 \%$ of pearl millet in diets for growing and finishing pigs meets the nutritional requirements of the animals in these phases, and it is economically viable when the pearl millet commercial price corresponds to up to $70 \%$ of the corn price.

No effects of inclusion of pearl millet to the diets was observed over the performance characteristics of the rabbits from weaning to the slaughter phase; also, the cost of feed per kilogram of weight gain is not altered as the level of pearl millet is increased. For these reasons, one can assume that, at the prices established, the total substitution of corn by pearl millet ADR 7010 seems to be viable.

No difference was observed $(\mathrm{P}>0.05)$ in the results of carcass weight and carcass yield and commercial cuts of rabbits as corn was replaced by pearl millet (Table 6).

The results found were similar to the ones found by Furlan et al. (2003), using common pearl millet and IAPAR to gradually substitute corn, with values of $1,069 \mathrm{~g}$ and $48.30 \%$ and $1,087 \mathrm{~g}$ and $48.46 \%$, respectively, for carcass weight and carcass productivity of rabbits in the two cultivars studied. Bastos et al. (2002) concluded that the inclusion of up to $60 \%$ of pearl millet in diets for growing pigs did not cause any alteration in the carcass characteristics of pigs. Bastos et al. (2005), working with substitution levels of up to $100 \%$ of corn by pearl millet, did not find any differences in the carcass of pigs.

Table 6 - Characteristics of carcass of rabbits fed reference diet and different levels of pearl millet ADR 7010, slaughtered at 70 days of age

\begin{tabular}{|c|c|c|c|c|c|c|c|c|}
\hline \multirow[t]{2}{*}{ Characteristics } & \multirow[t]{2}{*}{ Reference diet } & \multicolumn{5}{|c|}{$\%$ of substitution of corn by pearl millet } & \multirow[t]{2}{*}{ Average } & \multirow[t]{2}{*}{ CV (\%) } \\
\hline & & 20 & 40 & 60 & 80 & 100 & & \\
\hline \multicolumn{9}{|c|}{ Weight（g） } \\
\hline Carcass & 1146 & 1163 & 1148 & 1156 & 1169 & 1086 & 1143 & 12.24 \\
\hline Hindquarter & 376 & 387 & 380 & 383 & 384 & 364 & 379 & 11.62 \\
\hline Loin & 277 & 278 & 272 & 277 & 280 & 253 & 272 & 16.41 \\
\hline Forequarter & 137 & 143 & 142 & 141 & 139 & 132 & 139 & 12.82 \\
\hline $\mathrm{TCP}$ & 249 & 250 & 249 & 250 & 261 & 233 & 248 & 16.61 \\
\hline \multicolumn{9}{|c|}{ Productivity (\%) } \\
\hline Carcass & 53.19 & 52.86 & 53.16 & 53.96 & 54.10 & 53.80 & 53.57 & 4.21 \\
\hline Hindquarter & 32.90 & 33.41 & 33.20 & 33.19 & 33.33 & 33.63 & 33.29 & 3.46 \\
\hline Loin & 24.06 & 23.85 & 23.73 & 24.18 & 24.43 & 23.03 & 23.68 & 7.55 \\
\hline Forequarter & 12.05 & 12.38 & 12.40 & 12.27 & 12.30 & 12.32 & 12.27 & 7.65 \\
\hline TC P & 21.74 & 21.54 & 21.72 & 21.58 & 22.34 & 21.25 & 21.66 & 8.40 \\
\hline
\end{tabular}

TCP - Thoracic-cervical region.

\section{Conclusions}

The values of digestible dry matter, digestible protein, digestible neutral detergent fiber, digestible acid detergent fiber and digestible energy of milled pearl millet grains for rabbits were, respectively, $81.25 \%, 11.77 \%, 0.3 \%$ and $3,361 \mathrm{kcal}$ of digestible energy/kg of dry matter. Milled pearl millet grain can completely substitute corn in diets for growing rabbits. 


\section{References}

ADEOLA, O.; ORBAN, J.I. Chemical composition and nutrient digestibility of pearl millet (Pennisetum glaucum) fed to growing pigs. Journal of Cereal Science, v.22, p.177-184, 1995.

BASTOS, A.O.; FILHO, L.C.L.; PASSIPIERI, M. et al. Diferentes níveis de grão de milheto (Pennisetum americanum L. Leeke) na alimentação de suínos. Revista Brasileira de Zootecnia, v.31, n.4, p.1753-1760, 2002.

BASTOS, A.O.; MOREIRA, I; FURLAN, A.C. et al. Composição química, digestibilidade dos nutrientes e da energia de diferentes milhetos (Pennisetum Glaucum (L.) R. Brown) em suínos. Revista Brasileira de Zootecnia, v.32, n.2, p.520-528, 2004.

BASTOS, A.O.; MOREIRA, I.; FURLAN, A.C. et al. Composição química, digestibilidade dos nutrientes e da energia de diferentes milhetos (Pennisetum glaucum (L.) R. Brown) em suínos. Revista Brasileira de Zootecnia, v.34, n.2, p.520-528, 2005.

BASTOS, A.O.; MOREIRA, I.; FURLAN, A.C. et al. Efeitos da inclusão de níveis crescentes de milheto (Pennisetum Glaucum (L.) R. Brown) grão na alimentação de suínos em crescimento e terminação. Revista Brasileira de Zootecnia, v.35, n.1, p.98-103, 2006.

BELLAVER, C.; FIALHO, E.T.; PROTAS, J.F.S. et al. Radícula de malte na alimentação de suínos em crescimento e terminação. Pesquisa Agropecuária Brasileira, v.20, n.8, p.969-974, 1985.

CAFÉ, M.B.; STRINGHINI, J.H.; FRANÇA, A.F.S. Utilização do milheto na alimentação animal. In: SIMPÓSIO SOBRE INGREDIENTES NA ALIMENTAÇÃO ANIMAL, 2., 2002. Uberlândia. Anais... Uberlândia: Colégio Brasileiro de Nutrição Animal, 2002. p.5-38.

DAVIS, A.J.; DALE, N.M.; FERREIRA, F.J. Pearl millet as an alternative feed ingredient in broiler diets. Journal of Applied Poultry Research, v.12, p.137-144, 2003.

DE BLAS, C.; WISEMAN, J. The nutrition of the rabbit. New York: CABI Publishing, 1998. 344p.

FOOD AND AGRICULTURE ORGANIZATION - FAO. FAOSTAT 2005: FAO statistical databases. 2008. Available at: <www.fao.org.br $>$. Accessed on: Sept. 19, 2008.

FIALHO, E.T.; LIMA, J.A.F.; FRANGILO, R.S. et al. Uso de ensaios de metabolismo para determinação dos valores nutricionais de alguns alimentos com suínos. In: REUNIÃO ANUAL DA SOCIEDADE BRASILEIRA DE ZOOTECNIA, 36., 1999, Porto
Alegre. Anais... São Paulo: Sociedade Brasileira de Zootecnia/ Gmosis, 1999. (CD-ROM).

FURLAN, A.C.; SCAPINELLO, C.; TORAL, F.L.B. et al. Valor nutritivo e desempenho de coelhos alimentados com rações contendo milheto (Pennisetum glaucum (L.) R.Br). Revista Brasileira de Zootecnia, v.32, n.1, p.123-131, 2003.

GERALDO, J.; ROSSIELLO, R.O.P.; ARAÚJO, A.P. et al. Diferenças em crescimento e produção de grãos entre quatro cultivares de milheto-pérola. Pesquisa Agropecuária Brasileira, v.35, n.7, p.1367- 1376, 2000.

GOMES, P.C.; RODRIGUES, M.P.; ALBINO, L.F.T. et al. Determinação da composição química e energética do milheto e sua utilização em rações para frangos de corte de 1 a 21 dias de idade. Revista Brasileira de Zootecnia, v.37, n.9, p.1617-1621, 2008.

LAWRENCE, B.V.; ADEOLA, O.; ROGLER, J.C. Nutrient digestibility and growth performance of pigs fed pearl millet as replacement for corn. Journal of Animal Science, v.73, p.2026-2032, 1995.

MATTERSON, L.D.; POTTER, L.M.; STUTZ, M.W. et al. The metabolizable energy of feed ingredients for chickens. Storrs, Connecticut University of Connecticut, Agricultural Experiment Station, Research Report, v.7, n.1, p.11-14, 1965.

MURAKAMI, A.E.; SOUZA, L.M.G.; MASSUDA, E.M. et al. Avaliação econômica e desempenho de frangos de corte alimentados com diferentes níveis de milheto em substituição ao milho. Acta Scientiarum Animal Sciences, v.3, n.1, p.31-37, 2009.

PÉREZ. J.M.; LEBAS, F.; GIDENNE, T. et al. European reference method for in vivo determination of diet digestibility in rabbits. World Rabbit Science, v.3, n.1, p.41-43, 1995.

PINHEIRO, M.S.M.; FIALHO, E.T.; LIMA, J.A.F. et al. Milheto moído em substituição ao milho em rações para suínos em crescimento: digestibilidade e desempenho. Revista Brasileira de Milho e Sorgo, v.2, n.2, p.99-109, 2003.

RODRIGUES, P.B.; ROSTAGNO, H.S.; ALBINO, L.F.T. et al. Valores energéticos do milheto, do milho e subprodutos do milho, determinados com frangos de corte e galos adultos. Revista Brasileira de Zootecnia, v.30, n.6, p.1767-1778, 2001.

ROSTAGNO, H.S.; ALBINO, L.F.T.; DONZELE, J.L. et al. Tabelas brasileiras para aves e suínos: composição de alimentos e exigências nutricionais. 2.ed. Viçosa, MG: Editora UFV, 2005. 186p.

SILVA, D.J.; QUEIROZ, A.C. Análise de alimentos - métodos químicos e biológicos. 3.ed. Viçosa, MG: Universidade Federal de Viçosa, 2002. 235p. 